\title{
PENARAPAN LQ DAN SHIFT SHARE DALAM MENGUKUR PERTUMBUHAN EKONOMI DI PROVINSI SULAWESI SELATAN PERIODE TAHUN 2013-2017
}

\author{
Muh. Fuad Randy, Muh. Indra Fauzi Ilyas, Abdul Sumarlin \\ STIE YPUP Makassar
}

\begin{abstract}
Testing the Application of Location Quotient (LQ) and Shift Share in Measuring Economic Growth in South Sulawesi Province for the 2013-2017 Period. Based on the fluctuating conditions of labor changes and the contribution of GDP to the structure of the economy in the provinces of South Sulawesi and Indonesia. The main problem in this study is; What is the economic growth of South Sulawesi province based on the shift share approach for the 2013-2017 period, what is the economic growth of South Sulawesi province based on the LQ approach for the 2013-2017 period, the results of the calculation of GRDP 2013-2017 that have been made can be concluded as follows; There are 8 (eight) sectors which are the base sectors including the first sector of agriculture, both water supply, waste management, waste and recycling, third construction, fourth information and communication, fifth real estate, sixth government administration, defense and social security, seven services Education, eight health services and social activities there are four sectors that have the advantage of the first, namely the agricultural sector, the second processing industry, the third construction sector, the fourth large and retail trade, car and motorcycle repair
\end{abstract}

Keywords: Location quotient (LQ), Shift Share Analysis, Growth Potential

\begin{abstract}
ABSTRAK
Menguji Penerapan Location Quotient (LQ) dan Shift Share Dalam Mengukur Pertumbuhan Ekonomi Pada Provinsi Sulawesi Selatan Periode Tahun 2013-2017. Didasarkan adanya kondisi fluktuatif perubahan tenaga kerja dan kontribusi PDRB struktur perekonomian di Provinsi Sulawesi Selatan dan Indonesia. Pokok permasalahan dalam penelitian ini adalah; Bagaimana pertumbuhan ekonomi provinsi Sulawesi Selatan berdasarkan pendekatan shift share periode tahun 2013-2017, bagaimana pertumbuhan ekonomi provinsi Sulawesi Selatan berdasarkan pendekatan LQ periode tahun 2013- 2017, hasil perhitungan PDRB 2013-2017 yang telah dilakukan dapat diambil kesimpulan sebagai berikut; Terdapat 8 (delapan) sektor yang merupakan sektor basis diantaranya sektor pertama pertanian, kedua Pengadaan air, pengelolaan sampah, limbah dan daur ulang, ketiga Konstruksi, keempat informasi dan komunikasi, kelima real estate, keenam administrasi pemerintahan, pertahanan dan jaminan sosial, ketujuh jasa Pendidikan, kedelapan jasa kesehatan dan kegiatan sosial terdapat empat sektor yang memiliki keunggulan yakni pertama sektor pertanian, kedua Industri pengolahan, ketiga sektor konstruksi, keempat perdagangan besar dan eceran, reparasi mobil dan sepeda motor
\end{abstract}

Kata Kunci: Location quotient (LQ), Analisis Shift Share, Potensi Pertumbuhan 


\section{PENDAHULUAN}

Kecenderungan wilayah yang berkembang dalam rangka meningkatkan taraf hidup dan kesejahteraan masyarakatnya adalah dengan pembangunan disektor industri, pertanian, perdagangan dan jasa karena dianggap lebih mampu meningkatkan perekonomian dan menumbuhkan berbagai kegiatan yang saling berkaitan sehingga mampu berfungsi sebagai pendorong pembangunan. Proses pertumbuhan ekonomi ini pada akhirnya akan menyebabkan terjadinya transformasi struktural, yaitu proses pergeseran pertumbuhan sektor produksi dari yang semula mengandalkan sektor primer menuju sektor sekunder. Pergeseran pertumbuhan sektor produksi ini secara langsung juga akan berpengaruh pada perubahan komposisi tenaga kerja.

Tabel 1.1.

Nilai Produk Domestik Bruto Menurut Lapangan Usaha Atas Dasar Harga Berlaku Di Sulawesi Selatan

Tahun 2008 - 2013

\begin{tabular}{|l|r|r|r|r|r|r|}
\hline \multirow{2}{*}{ Lapangan Usaha } & \multicolumn{5}{|c|}{ TAHUN } \\
\cline { 2 - 7 } & \multicolumn{1}{|c|}{$\mathbf{2 0 0 8}$} & $\mathbf{2 0 0 9}$ & \multicolumn{1}{c|}{$\mathbf{2 0 1 0}$} & \multicolumn{1}{c|}{$\mathbf{2 0 1 1}$} & \multicolumn{1}{c|}{$\mathbf{2 0 1 2}$} & \multicolumn{1}{c|}{2013} \\
\hline Pertanian & 25071.81 & 28008.21 & 30442.43 & 34788.23 & 39616.82 & 44162.54 \\
\hline $\begin{array}{l}\text { Pertambangan dan } \\
\text { Penggalian }\end{array}$ & 6201.50 & 5503.78 & 7119.68 & 8345.81 & 8961.89 & 11063.89 \\
\hline Industri Pengolahan & 11060.44 & 12514.89 & 14457.26 & 16789.29 & 19408.06 & 22559.13 \\
\hline $\begin{array}{l}\text { Listrik, Gas, dan } \\
\text { Air Bersih }\end{array}$ & 838.10 & 949.24 & 1087.97 & 1245.91 & 1439.21 & 1661.40 \\
\hline Konstruksi & 4253.53 & 5387.79 & 6534.51 & 7760.90 & 9071.24 & 10788.20 \\
\hline $\begin{array}{l}\text { Perdagangan, Hotel, } \\
\text { dan Restoran }\end{array}$ & 13913.80 & 16690.29 & 20434.95 & 24241.35 & 28748.16 & 33031.58 \\
\hline $\begin{array}{l}\text { Pengangkutan dan } \\
\text { Komunikasi }\end{array}$ & 6972.02 & 7953.95 & 9445.57 & 10849.77 & 12982.89 & 14867.28 \\
\hline $\begin{array}{l}\text { Keuangan, } \\
\text { Persewaan, dan Jasa }\end{array}$ & 11629 & 16704.94 & 20529.72 & 23984.82 & 27828.39 & 32064.22 \\
\hline Jasa-jasa & $\mathbf{8 5 1 4 3 . 2 0}$ & $\mathbf{9 9 9 5 4 . 6 1}$ & $\mathbf{1 1 7 8 6 2 . 2 1}$ & $\mathbf{1 3 7 5 1 9 . 7 7}$ & $\mathbf{1 5 9 8 5 9 . 9 3}$ & $\mathbf{1 8 4 7 8 3 . 0 6}$ \\
\hline PDRB & 5203 & 6241.52 & 7810.11 & 9513.69 & 11803.27 & 14584.81 \\
\hline
\end{tabular}

Sumber : BPS Provinsi Sulawesi Selatan 2012-2014 
Dengan berdasarkan tabel 1.1 juga dilihat perekonomian di provinsi Sulawesi Selatan dari tahun 2008 - 2013 mengalami fluktuasi.Oleh karena itu, pemerintah daerah harus mengetahui penyebab serta solusi dari pengaruh terjadinya perubahan struktrur ekonomi dengan melakukan berbagai analisa terhadap perubahan yang variatif terhadap berbagai sektor pertumbuhan ekonomi tersebut.

Menurut data BPS yang dimuat pada Berita Resmi Statistik No.45/05/Th.XVIII, 5 Mei 2015 tentang Pertumbuhan ekonomi sulawesi selatan triwulan 1 untuk tahun 2015 tumbuh sebesar 5,23\% melambat bila dibanding dengan triwulan 1 tahun 2014 sebesar 8,4\%. Kemudian dari sisi produksi, pertumbuhan tertinggi dicapai oleh lapangan usaha jasa lainnya sebesar 9,42\%, dan untuk pengeluaran dicapai oleh komponen PMTB yang tumbuh 7,13\%. Perekonomian Sulawesi Selatan yang diukur berdasarkan besaran produk domestik bruto (PDRB) atas dasar harga berlaku pada triwulan 1 tahun 2015 mencapai Rp. 78.496 milyar dan kemudian atas dasar harga konstan 2010 mencapai Rp. 58.484 milyar. Ekonomi Sulawesi Selatan triwulan I tahun 2015 melambat terhadap triwulan sebelumnya sebesar 0,23 persen. Akan tetapi, dari sisi produksi terjadi pertumbuhan yang disebabkan oleh faktor musiman pada lapangan usaha pertanian, kehutanan, dan perikanan yang tumbuh 18,95 persen. Sedangkan dari sisi pengeluaran lebih disebabkan oleh komponen konsumsi rumah tangga yang tumbuh sebesar 0,55 persen serta terkontraksinya kinerja komponen lainnya.

\section{MASALAH PENELITIAN}

Didasarkan adanya kondisi fluktuatif perubahan tenaga kerja dan kontribusi PDRB struktur perekonomian di Provinsi Sulawesi Selatan dan Indonesia. Olehnya, diambil pokok permasalahan dalam penelitian ini adalah ;

1. Bagaimana pertumbuhan ekonomi provinsi Sulawesi Selatan berdasarkan pendekatan shift share periode tahun 2013-2017?

2. Bagaimana pertumbuhan ekonomi provinsi Sulawesi Selatan berdasarkan pendekatan LQ periode tahun 2013- 2017?

Tujuan dari penelitian ini adalah untuk menganilisis pertumbuhan ekonomi provinsi Sulawesi Selatan berdasarkan pendekatan shift share dan pendekatan LQ periode tahun 2013-2017, kemudian adapun kegunaan dari penelitian ini adalah dapat digunakan oleh pemerintah dalam pertimbangan perencanaan strategi ekonomi di wilayah provinsi Sulawesi Selatan, serta dalam melihat pergeseran-pergeseran struktur ekonomi dari tahun ke tahun, juga dapat memberikan manfaat positif bagi penelitan-penelitian selanjutnya. 


\section{KAJIAN TEORITIS}

A. Teori Pertumbuhan Ekonomi Wilayah

Terdapat beberapa teori pertumbuhan ekonomi daerah/wilayah sebagai berikut :

1). Teori Basis Ekonomi Asumsi ini memberikan pengertian bahwa suatu daerah akan mempunyai sektor unggulan apabila daerah tersebut dapat memenangkan persaingan pada sektor yang sama dengan daerah lain sehingga dapat menghasilkan ekspor. Untuk menganalisis basis ekonomi suatu wilayah, salah satu teknik yang lazim digunakan adalah kuosien lokasi (Location Quotient, LQ).Location Quotient digunakan untuk mengetahui seberapa besar tingkat spesialisasi sektor-sektor basis atau unggulan (leading sectors).Dalam teknik $L Q$ berbagai peubah (faktor) dapat digunakan sebagai indikator pertumbuhan wilayah, misalnya kesempatan kerja (tenaga kerja) dan Produk Domestik Regional Bruto (PDRB) suatu wilayah.

2) Terdapat beberapa alat analisis yang digunakan untuk menentukan potensi relatif perekonomian suatu wilayah, sebagai berikut:

(a). Analisis Shift Share

Analisis Shift Share merupakan teknik yang sangat berguna dalam menganalisis perubahan struktur ekonomi daerah dibandingkan dengan perekonomian nasional.Tujuan analisis ini adalah untuk menentukan kinerja atau produktivitas kerja perekonomian daerah dengan membandingannya dengan daerah yang lebih besar (regional/nasional).Analisis ini memberikan data tentang kinerja perkonomian.

(b). Location Quotients

Dalam analisis ini kegiatan ekonomi suatu daerah dibagi menjadi 2 golongan, yaitu:

(1). Sektor Basis adalah kegiatan ekonomi yang melayani pasar di daerah itu sendiri maupun di luar daerah yang bersangkutan.

(2). Sektor Non Basis adalah kegiatan ekonomi yang melayani pasar di daerah itu sendiri. Metode LQ digunakan untuk mengidentifikasikan komoditas unggulan diakomodasi dari Miller dan Wright (1991), Isserman (1997), dan Ron Hood (1998). Menurut Hood (1998), Location Quostient adalah suatu alat pengembangan ekonomi yang lebih sederhana dengan segala kelebihan dan keterbatasannya. Teknik LQ merupakan salah satu pendekatan yang umum digunakan dalam model ekonomi basis sebagai langkah awal untuk memahami sektor kegiatan yang menjadi pemacu pertumbuhan. 


\section{METODOLOGI PENELITIAN}

\section{Lokasi Dan Waktu Penelitian}

Penelitian ini dilaksanakan di BPS provinsi Sulawesi Selatan Kota Makassar,dan waktu penelitian dilakukan selama 3 (tiga) bulan.

\section{Jenis dan Sumber Data}

Jenis dalam penelitian ini adalah menggunakan data sekunder yang diperoleh melalui studi kepustakaan dan mencatat teori-teori dari buku-buku literatur, bacaan-bacaan yang berhubungan dengan masalah yang diteliti.Sumber data Instansi-instansi pemerintahan seperti BPS (Badan Pusat Statistik) Provinsi Sulawesi Selatan, Badan Perencanaan Pembangunan Derah Sulawesi Selatan (BAPPEDA) serta instansi-instansi lain yang terkait.

\section{Metode Pengumpulan Data}

Untuk kepentingan penelitian ini digunakan data sekunder melalui metode dokumentasi berupa data PDRB Propinsi Sulawesi Selatan tahun 2013-2017 (data terbaru) atas dasar harga berlaku dan atas dasar harga konstan yang bersumber dari dokumentasi BPS.

\section{Populasi dan Sampel}

Dalam penelitian ini, menggunakan populasi seluruh data kualitatif dan kuantitatif tentang pertumbuhan ekonomi yang diperoleh dari kantor BPS dan Bapeda provinsi Sulawesi Selatan. Adapun sampel yang digunakan adalah data kuantitatif dan kualitatif pertumbuhan ekonomi periode 2013-2017 yang diperoleh dari kantor BPS dan Bapeda provinsi Sulawesi Selatan.

\section{Metode Analisis}

\section{Analisis LQ}

Teknik ini membandingkan tentang besarnya peranan suatu sektor disuatu daerah terhadap besarnya peranan sektor tersebut ditingkat nasional.Teknik ini digunakan untuk mengidentifikasi potensi internal yang dimiliki daerah tersebut yaitu sektor basis dan yang merupakan sektor basis (non basis).

Perhitungan LQ menggunakan rumus sebagai berikut (Warpani, 1984) :

$\begin{array}{ll}\text { LQ } & \text { : Nilai Location Quotient } \\ \mathrm{Si} & : \text { PDRB Sektor i di Sulawesi Selatan } \\ \mathrm{S} & : \text { PDRB total di Sulawesi Selatan } \\ \mathrm{Ni} & : \text { PDRB Sektor i di Sulawesi Selatan } \\ \mathrm{N} & : \text { PDRB total di Sulawesi Selatan }\end{array}$

$\mathrm{LQ}=\frac{\mathrm{SiS}}{\mathrm{N}} \mathrm{Ni}$




\section{Kriteria :}

$\mathrm{LQ} \geq 1$ : sektor usaha dikategorikan sektor basis

LQ $<1$ : sektor usaha dikategorikan sektor non basis.

\section{Analisis Shift Share}

Adalah analisis yang bertujuan untuk menentukan kinerja atau produktivitas kerja perekonomian daerah dengan membandingkannya dengan daerah yang lebih besar (regional atau nasional). Teknik analisis shift share ini membagi pertumbuhan sebagai perubahan (D) suatu variabel wilayah, seperti tenaga kerja, nilai tambah, pendapatan atau output, selama kurun waktu tertentu menjadi pengaruhpengaruh : pertumbuhan nasional (N), industri mix/bauran industry (M), dan keunggulan kompetitif ( C ).

Menurut Prasetyo Soepomo (1993) bentuk umum persamaan dari analisis shift share dan komponen-komponennya adalah :

$$
D \mathbf{i j}=\mathbf{N} \mathbf{i j}+M \mathbf{i j}+\mathbf{C} \mathbf{i j}
$$

Keterangan :

$\mathrm{i}=$ Sektor-sektor ekonomi yang diteliti

$\mathrm{j} \quad \quad=$ Variabel wilayah yang diteliti Provinsi Sulawesi Selatan

$\mathrm{n} \quad=$ Variabel wilayah Indonesia

D ij $\quad=$ Perubahan sektor i di daerah $\mathrm{j}$ (Provinsi Sulsel)

$\mathrm{N} \mathrm{ij} \quad=$ Pertumbuhan nasional sektor $\mathrm{i}$ di daerah $\mathrm{j}$ (Provinsi Sulsel)

$\mathrm{M}$ ij $\quad=$ Bauran industri sektor i di daerah $\mathrm{j}$ (Provinsi Sulsel)

$\mathrm{C}$ ij $\quad=$ Keunggulan kompetitif sektor i di daerah $\mathrm{j}$ (Provinsi Sulsel)

Dalam penelitian ini variabel yang digunakan adalah Tenaga Kerja dan PDRB Sulawesi Selatan serta PDRB Indonesia yang dinotasikan sebagai (y). maka :

$$
\begin{aligned}
& \text { D ij } \quad=y * i j-y i j \\
& \mathrm{Nij} \quad=y i j . r n \\
& \text { Mij } \quad=y i j(r i n-r n) \\
& \mathrm{C} \mathrm{ij} \quad=y i j(r i j-r i n)
\end{aligned}
$$

Keterangan :

y ij $\quad=$ Tenaga Kerja/PDRB sektor i di daerah $\mathrm{j}$ (Provinsi Sulsel)

$\mathrm{y}^{*} \mathrm{ij} \quad=$ Tenaga Kerja/PDRB sektor $\mathrm{i}$ di daerah $\mathrm{j}$ akhir tahun analisis (Provinsi Sulsel)

$\mathrm{r}$ ij = Laju pertumbuhan sektor i di daerah $\mathrm{j}$ (Provinsi Sulsel)

$\mathrm{r}$ in $\quad=$ Laju pertumbuhan sektor $\mathrm{i}$ di daerah $\mathrm{n}$ (Indonesia)

$\mathrm{r} \mathrm{n} \quad=$ Rata-rata Laju pertumbuhan Tenaga Kerja/GNP di daerah $\mathrm{n}$ (Indonesia) 


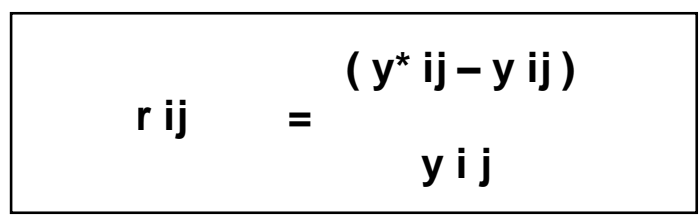

$\mathrm{y}$ in $=$ Tenaga kerja/GNP sektor $\mathrm{i}$ di daerah $\mathrm{n}$ (Indonesia)

$\mathrm{y}^{*}$ in $=$ Tenaga kerja/GNP sektor $\mathrm{i}$ di daerah $\mathrm{n}$ akhir tahun analisis Indonesia)

$\mathrm{y} \mathrm{n} \quad=$ Total Tenaga kerja/GNP semua sektor di daerah $\mathrm{n}$ (Indonesia)

$\mathrm{y}^{*} \mathrm{n}=$ Total Tenaga Kerja/GNP semua sektor di daerah $\mathrm{n}$ (Indonesia) akhir tahun analisis

Untuk suatu daerah, pertumbuhan nasional / regional, bauran industri dan keunggulan kompetitif dapat dijumlahkan untuk semua sektor sebagai keseluruhan daerah, sehingga persamaan shift share untuk sektor I di wilayah j adalah:

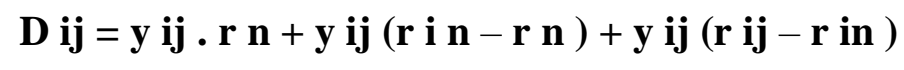




\section{PEMBAHASAN}

1. Hasil perhitungan Location Quotient (LQ) adalah sebagai berikut:

Tabel 2.1 PDRB Provinsi Sulawesi Selatan 2013-2017

\begin{tabular}{|c|c|c|c|c|c|c|c|}
\hline \multirow{2}{*}{\multicolumn{2}{|c|}{ No. Lapangan Usaha }} & \multicolumn{5}{|c|}{ Tahun } & \multirow[t]{2}{*}{ Rata-rata } \\
\hline & & 2013 & 2014 & 2015 & 2016 & 2017 & \\
\hline 1 & Pertanian & 57367.11 & 68465.44 & 78781.76 & 88328.46 & 95895.43 & 312121.86 \\
\hline 2 & $\begin{array}{l}\text { Pertambangan dan } \\
\text { Penggalian }\end{array}$ & 17883.29 & 21181.98 & 21521.03 & 21231.33 & 22474.98 & 86312.626 \\
\hline 3 & Industri Pengolahan & 35486.79 & 41652.14 & 47250.08 & 53017.47 & 57449.33 & 188896.35 \\
\hline 4 & Pengadaan Listrik dan Gas & 177.43 & 204.64 & 193.48 & 219.86 & 268.71 & 849.152 \\
\hline 5 & $\begin{array}{l}\text { Pengadaan Air, } \\
\text { Pengelolaan Sampah, } \\
\text { Limbah dan Daur ulang }\end{array}$ & 354.76 & 354.76 & 369.75 & 394 & 430.77 & 1559.424 \\
\hline 6 & Konstruksi & 31516.2 & 36015.37 & 42181.43 & 47501.08 & 53386.35 & 167891.35 \\
\hline 7 & $\begin{array}{l}\text { Perdagangan Besar dan } \\
\text { Eceran, Reparasi Mobil dan } \\
\text { Sepeda Motor }\end{array}$ & 33633.47 & 37623.8 & 43788.67 & 50836.85 & 58381.45 & 177559.08 \\
\hline 8 & $\begin{array}{l}\text { Transportasi dan } \\
\text { Pergudangan }\end{array}$ & 10426.5 & 11827.82 & 14245.73 & 16170.46 & 17514.08 & 56173.326 \\
\hline 9 & $\begin{array}{l}\text { Penyediaan Akomodasi dan } \\
\text { Makan/Minum }\end{array}$ & 3563.98 & 4108.43 & 4548.96 & 4991.42 & 5696.25 & 18352.04 \\
\hline 10 & Informasi dan Komunikasi & 13785.12 & 14594.26 & 15715.16 & 17573.8 & 19933.01 & 65654.942 \\
\hline 11 & $\begin{array}{l}\text { Jasa Keuangan dan } \\
\text { Asuransi }\end{array}$ & 9597.1 & 10823.77 & 12256.57 & 14363.09 & 15797.24 & 50199.978 \\
\hline 12 & Real Estate & 9903.93 & 11523.07 & 13585.65 & 15093.51 & 16151.29 & 53336.418 \\
\hline 13 & Jasa Perusahaan & 1147.89 & 1297.15 & 1483.65 & 1652.58 & 1845.25 & 5950.32 \\
\hline 14 & $\begin{array}{l}\text { Administrasi Pemerintahan, } \\
\text { Pertahanan dan Jaminan } \\
\text { Sosial }\end{array}$ & 12240.14 & 13632.19 & 16286.08 & 16841.81 & 18194.82 & 62639.184 \\
\hline 15 & Jasa Pendidikan & 13885.86 & 15497.61 & 17300.51 & 19130.9 & 21756.45 & 70166.17 \\
\hline 16 & $\begin{array}{l}\text { Jasa Kesehatan dan } \\
\text { Kegiatan Sosial }\end{array}$ & 4682.43 & 5509.31 & 6515.54 & 7329.54 & 8188.61 & 25674.542 \\
\hline 17 & Jasa Lainnya & 3184.44 & 3722.08 & 4366.16 & 4956.08 & 5567.57 & 17342.274 \\
\hline & PDRB & 258836.44 & 298033.82 & 340390.21 & 379632.24 & 418931.59 & 1360679 \\
\hline
\end{tabular}

Sumber : BPS Sulawesi Selatan 2013-2017 (diolah) 
Tabel 2.2 hasil perhitungan LQ

\begin{tabular}{|c|c|c|c|c|c|c|c|c|}
\hline \multirow{2}{*}{\multicolumn{2}{|c|}{ No. Lapangan Usaha }} & \multicolumn{7}{|c|}{ C $=\mathrm{A} / \mathrm{B}=$ Analisis $\mathrm{LQ}=\mathrm{Si} / \mathrm{S} / \mathrm{Ni} / \mathrm{N}$} \\
\hline & & 2013 & 2014 & 2015 & 2016 & 2017 & $\mathrm{rata} / \mathrm{rata}$ & \\
\hline 1 & Pertanian & 1.618016 & 1.679877 & 1.661605 & 1.665695 & 1.674798 & 1.659998 & $\mathrm{LQ}>1$ \\
\hline 2 & $\begin{array}{l}\text { Pertambangan dan } \\
\text { Penggalian }\end{array}$ & 0.612063 & 0.704845 & 0.800636 & 0.75114 & 0.681392 & 0.710015 & $\mathrm{LQ}<1$ \\
\hline 3 & Industri Pengolahan & 0.635731 & 0.646729 & 0.640732 & 0.656529 & 0.6541 & 0.646764 & $\mathrm{LQ}<1$ \\
\hline 4 & $\begin{array}{l}\text { Pengadaan Listrik dan } \\
\text { Gas }\end{array}$ & 0.064657 & 0.061599 & 0.048881 & 0.048681 & 0.051627 & 0.055089 & $\mathrm{LQ}<1$ \\
\hline 5 & $\begin{array}{l}\text { Pengadaan Air, } \\
\text { Pengelolaan Sampah, } \\
\text { Limbah dan Daur } \\
\text { ulang }\end{array}$ & 1.769726 & 1.564965 & 1.419124 & 1.388655 & 1.382238 & 1.504942 & $\mathrm{LQ}>1$ \\
\hline 6 & Konstruksi & 1.250998 & 1.19553 & 1.17545 & 1.162679 & 1.18108 & 1.193147 & $\mathrm{LQ}>1$ \\
\hline 7 & $\begin{array}{l}\text { Perdagangan Besar } \\
\text { dan Eceran, Reparasi } \\
\text { Mobil dan Sepeda } \\
\text { Motor }\end{array}$ & 0.959076 & 0.916909 & 0.937011 & 0.979827 & 1.030099 & 0.964584 & $\mathrm{LQ}<1$ \\
\hline 8 & $\begin{array}{l}\text { Transportasi dan } \\
\text { Pergudangan }\end{array}$ & 0.999078 & 0.876064 & 0.80779 & 0.790169 & 0.742987 & 0.843218 & $\mathrm{LQ}<1$ \\
\hline 9 & $\begin{array}{l}\text { Penyediaan } \\
\text { Akomodasi dan } \\
\text { Makan/Minum }\end{array}$ & 0.442727 & 0.442595 & 0.436858 & 0.433319 & 0.458534 & 0.442807 & $\mathrm{LQ}<1$ \\
\hline 10 & $\begin{array}{l}\text { Informasi dan } \\
\text { Komunikasi }\end{array}$ & 1.453753 & 1.366272 & 1.269596 & 1.233087 & 1.205129 & 1.305567 & $\mathrm{LQ}>1$ \\
\hline 11 & $\begin{array}{l}\text { Jasa Keuangan dan } \\
\text { Asuransi }\end{array}$ & 0.932459 & 0.916581 & 0.865699 & 0.870419 & 0.862709 & 0.889574 & $\mathrm{LQ}<1$ \\
\hline 12 & Real Estate & 1.347715 & 1.352988 & 1.360269 & 1.357294 & 1.326445 & 1.348942 & $\mathrm{LQ}>1$ \\
\hline 13 & Jasa Perusahaan & 0.285474 & 0.270287 & 0.255774 & 0.246125 & 0.241601 & 0.259852 & $\mathrm{LQ}<1$ \\
\hline 14 & $\begin{array}{l}\text { Administrasi } \\
\text { Pemerintahan, } \\
\text { Pertahanan dan } \\
\text { Jaminan Sosial }\end{array}$ & 1.182666 & 1.165272 & 1.188751 & 1.106347 & 1.129937 & 1.154595 & $\mathrm{LQ}>1$ \\
\hline 15 & Jasa Pendidikan & 1.622044 & 1.568153 & 1.464039 & 1.441306 & 1.518819 & 1.522872 & $\mathrm{LQ}>1$ \\
\hline 16 & $\begin{array}{l}\text { Jasa Kesehatan dan } \\
\text { Kegiatan Sosial }\end{array}$ & 1.738112 & 1.745838 & 1.734842 & 1.742897 & 1.761812 & 1.7447 & $\mathrm{LQ}>1$ \\
\hline 17 & Jasa Lainnya & 0.816157 & 0.78715 & 0.751468 & 0.738714 & 0.726211 & 0.76394 & $\mathrm{LQ}<1$ \\
\hline
\end{tabular}

Sumber : BPS Propinsi Sulawesi Selatan Periode 2013-2017 
Hasil perhitungan LQ menghasilkan dua kriteria yaitu:

$\mathrm{LQ} \geq 1 \quad$ : sektor usaha dikategorikan sektor basis

Artinya komoditas menjadi basis atau menjadi sumber pertumbuhan. Komoditas memiliki keunggulan komparatif karena hasilnya tidak saja dapat memenuhi kebutuhan di wilayah bersangkutan akan tetapi juga dapat diekspor ke luar wilayah.

LQ $<1 \quad$ : sektor usaha dikategorikan sektor non basis

Artinya komoditas di suatu wilayah tidak dapat memenuhi kebutuhan sendiri sehingga perlu pasokan atau impor dari luar.

Hasil analsis LQ sesuai dengan perhitungan tabel 2.2 menunjukkan :

a. Pertanian $(1,6)$, Pengadaan air, pengelolaan sampah, limbah dan daur ulang $(1,5)$, Konstruksi (1,2), informasi dan komunikasi (1,3), Real Estate (1,3), Administrasi Pemerintahan, Pertahanan dan Jaminan Sosial $(1,2)$, Jasa Pendidikan $(1,5)$, Jasa Kesehatan dan Kegiatan Sosial $(1,7)$.

b. Pertambangan dan penggalian $(0,7)$, Industri Pengolahan $(0,6)$, Pengadaan Listrik dan Gas (0,05), Perdagangan Besar dan Eceran, Reparasi Mobil dan Sepeda Motor $(0,9)$, Transportasi dan Pergudangan (0,8), Penyediaan Akomodasi dan Makan/Minum $(0,4)$, Jasa Keuangan dan Asuransi $(0,8)$, Jasa Perusahaan $(0,25)$, Jasa Lainnya $(0,76)$.

2. Hasil Perhitungan Analisis Shift Share (SS)

Merupakan analisis yang bertujuan untuk menentukan kinerja atau produktivitas kerja perekonomian daerah dengan membandingkannya dengan daerah yang lebih besar semisal Propinsi Sulawesi Selatan dan Indonesia. Teknik analisa ini membagi pertumbuhan sebagai perubahan (D) suatu variabel wilayah, seperti tenaga kerja, nilai tambah, pendapatan atau output, selama kurun waktu tertentu menjadi pengaruh: pertumbuhan nasional $(\mathrm{N})$, industry bauran (M), dan keunggulan kompetetif (C).

Menurut Prasetyo Soepomo (1993) bentuk umum persamaan dari analisis shift share dan komponennya adalah :

$\mathrm{Dij}=\mathrm{Nij}+\mathrm{Mij}+\mathrm{Cij}$

Keterangan:

$\mathrm{i} \quad=$ Sektor-sektor ekonomi yang diteliti

$\mathrm{j} \quad=$ variabel wilayah yang diteliti Propinsi Sulawesi Selatan 
$\mathrm{n} \quad=$ variabel wilayah indonesia

Dij = perubahan sektor I di daerah $\mathrm{j}$ (Propinsi Sulawesi Selatan)

$\mathrm{Nij} \quad=$ pertumbuhan nasional sektor I di daerah $\mathrm{j}$ (Propinsi Sulawesi Selatan)

Mij = bauran industry sektor I di daerah j (Propinsi Sulawesi Selatan)

Cij = keunggulan kompetetif sektor I di daerah $\mathrm{j}$ (Propinsi Sulawesi Selatan)

Dalam penelitian ini variabel yang digunakan adalah tenaga kerja atau PDRB yang di notasikan sebagai $(\mathrm{y})$, sehingga :

Dij $\quad=y * i j-y i j$

$\mathrm{Nij} \quad=y i j \cdot r n$

Mij $\quad=y i j(r$ in $-r n)$

Cij = yij (rin-r in)

Keterangan:

Yij = Tenaga kerja atau PDRB sektor I di daerah $\mathrm{j}$ (Provinsi Sulawesi Selatan)

$\mathrm{Y}^{*} \mathrm{ij}=$ Tenaga kerja atau PDRB sektor $\mathrm{I}$ di daerah $\mathrm{j}$ akhir tahun analisis (Provinsi Sulawesi Selatan)

rij = Laju pertumbuhan sektor I di daerah j (Provinsi Sulawesi Selatan)

$\mathrm{r}$ in $\quad=$ Laju pertumbuhan sektor I di daerah $\mathrm{n}$ (Indonesia)

$\mathrm{r} \mathrm{n} \quad=$ Rata-rata laju pertumbuhan tenaga kerja/GNP di daerah $\mathrm{n}$ (Indonesia)

rij $\quad=\frac{(y * i j-y ~ i j)}{y i j}$

\begin{tabular}{lcc}
\hline Lapangan Usaha & 4.09734751 & Rata-rata \\
Pertanian & sektor yang memiliki keunggulan \\
Pertambangan dan Penggalian & 0.65677868 & tidak memiliki keunggulan \\
Industri Pengolahan & 3.81506411 & sektor yang memiliki keunggulan \\
Pengadaan Listrik dan Gas & 0.00090843 & tidak memiliki keunggulan \\
$\begin{array}{l}\text { Pengadaan Air, Pengelolaan } \\
\text { Sampah, Limbah dan Daur ulang }\end{array}$ & 0.00011363 & tidak memiliki keunggulan \\
Konstruksi & 1.67328785 & sektor yang memiliki keunggulan
\end{tabular}


Perdagangan Besar dan Eceran, Reparasi Mobil dan Sepeda Motor

Transportasi dan Pergudangan

Penyediaan Akomodasi dan Makan/Minum

Informasi dan Komunikasi

Jasa Keuangan dan Asuransi

Real Estate

Jasa Perusahaan

Administrasi Pemerintahan, Pertahanan dan Jaminan Sosial

Jasa Pendidikan

Jasa Kesehatan dan Kegiatan

Sosial

Jasa Lainnya

Sumber : BPS Sulawesi Selatan 2013-2017 (data diolah), tabel 2.3
2.29588755 sektor yang memiliki keunggulan

$0.27482654 \quad$ tidak memiliki keunggulan

0.05248766 tidak memiliki keunggulan

$0.22290171 \quad$ tidak memiliki keunggulan

0.19887968 tidak memiliki keunggulan

0.14717009 tidak memiliki keunggulan

0.00963046 tidak memiliki keunggulan

$0.23252747 \quad$ tidak memiliki keunggulan

0.22491984 tidak memiliki keunggulan

$0.02697286 \quad$ tidak memiliki keunggulan

0.02840859 tidak memiliki keunggulan

Hasil analisis berdasarkan tabel 2.3 menunjukkan :

1. Terdapat empat sektor yang memiliki keunggulan yakni sektor pertanian sebesar 4.09734751, Industri pengolahan 3.81506411, sektor konstruksi sebesar 1.67328785, Perdagangan Besar dan Eceran, Reparasi Mobil dan Sepeda Motor 2.29588755

2. Kemudian terdapat 13 (tiga belas) sektor yang tidak memiliki keunggulan diantaranya adalah Pertambangan dan Penggalian sebesar 0.65677868, Pengadaan Listrik dan Gas 0.00090843, Pengadaan Air, Pengelolaan Sampah, Limbah dan Daur ulang sebesar 0.00011363, Transportasi dan Pergudangan 0.27482654, Penyediaan Akomodasi dan Makan/Minum 0.05248766, Informasi dan Komunikasi 0.22290171, Jasa Keuangan dan Asuransi 0.19887968, Real Estate 0.14717009, Jasa Perusahaan 0.00963046, Administrasi Pemerintahan, Pertahanan dan Jaminan Sosial 0.23252747, Jasa Pendidikan 0.22491984, Jasa Kesehatan dan Kegiatan Sosial 0.02697286, Jasa Lainnya 0.02840859. 


\section{KESIMPULAN}

Dari hasil perhitungan PDRB 2013-2017 yang telah dilakukan dapat diambil kesimpulan sebagai berikut:

1. Terdapat 8 (delapan) sektor yang merupakan sektor basis diantaranya sektor pertama pertanian, kedua Pengadaan air, pengelolaan sampah, limbah dan daur ulang, ketiga Konstruksi, keempat informasi dan komunikasi, kelima Real Estate, keenam Administrasi Pemerintahan, Pertahanan dan Jaminan Sosial, ketujuh Jasa Pendidikan, kedelapan Jasa Kesehatan dan Kegiatan Sosial

2. Terdapat empat sektor yang memiliki keunggulan yakni pertama sektor pertanian, kedua Industri pengolahan, ketiga sektor konstruksi, keempat Perdagangan Besar dan Eceran, Reparasi Mobil dan Sepeda Motor. 


\section{DAFTAR PUSTAKA}

Andjani, Ike Yuli \& Anggi Rahajeng. (2016). Analisis Kesempatan Kerja Sektoral Di Kabupaten Kulon Progo Provinsi Daera Istimewa Yogyakarta Dengan Pendekatan Pertumbuhan Sektor Basis. Yogyakarta: Universitas Gadja Mada Yogyakarta.

Alhasni, Syarifah Indah Permatasari.2017.Analisis Struktur Ekonomi Dan Pertumbuhan Ekonomi Di Kabupaten Karawang Tahun 2011-2015.Jakarta:Universitas Isalam Negeri Syarif Hidatulla Jakarta.

Badan Pusat Statistik (BPS). Sulawesi Selatan Produk Domestik Regional Bruto (PDRB). Tahun 2013-2017.

Badan Pusat Statistik (BPS). Indonesia Produk Domestik Regional Bruto (PDRB). Tahun 20132017.

Basuki, Mahmud \& Febri Nugroho Miraharjo.(2017).Analisis Sektor Unggulan Kabupaten Sleman Dengan Metode Shift Dan Location Quotiont.Japara, Palembang: Universitas Trinanti Palembang \& Unisnu Japara.

Fathurrohman, Asep.(2014).Analisis Potensi Sektoral Kabupaten/Kota Di Wilaya Iii Cirebon Tahun 2006-2012.Jakarta:Universitas Islam Negeri Syarif Hidayatullah.

Hajeri, Erlinda Yurisinthae, Eva Dolorosa.(2015).Analisis Penentuan Sektor Unggulan Perekonimian Di Kabupaten Kubu Raya.Pontianak:Universitas Tanjungpura

Herdiana, Dedi \& Khoiruddin. (2016).Peran Dan Strategi Humas Dalam Pembantuan Citra Perguruan Tinggi Islam.Bandung:Uin Sunan Gunung Djati Bandung.

Hapsari, Hening Pratika Nila.(2018).Analisis Pembangunan Wilaya Berbasis Sektor Unggulan Dan Strategi Pengembangannya.Yogyakarta:Universitas Muhamdiya Yogyakarta

Jati, Wisnu Trilung Waluyo.(2018).Analisis Potensi Sektor Perikanan Dalam Pertumbuhan Ekonomi Kota Tegal. Yogyakarta:Universitas Islam Indonesia Fakultas Ekonomi.

Janna, Miptahul. (2017).Analisis Potensi Unggulan Komuditi Taman Karet Rakyat Di Kabupaten Labuhan Batu Selatan.Medan :Fakultas Pertanian Universitas Medan Area.

Larasati, Indri.(2017).Analisis Fator-Faktor Yang Mempengaruhi Pertumbuhan Ekonomi Di Provinsi Daera Istimewa Yogyakarta Tahun 2010-2016.Yogyakarta:Fakultas Ekonomi Universitas Isalam Indonesia

Latumaerisa, Julius R. Perekonomian Indonesia Dan Dinamika Ekonomi Global. 2015. Penerbit Mitra Wacana Media. Jakarta.

Musyawara.(2016).Analisis Pertumbuhan Ekonomi Dan Pengangguran Di Sulawesi Selatan. Makassar;Universitas Negeri Makassar. 
Mangilaleng, E J, Debby Rotinsulu \& Wansi Rompas. (2015). Analisis Sektor Unggulan Kabupaten Minahasa Selatan. Manado : Universitas Sam Ratulangi Manado.

Pambudi, Eko Wicaksono., Miyasto.(2013). Analisis Pertumbuhan Ekonomi Dan Faktor-Faktor Yang Mempengaruhi (Kabupaten/Kota Di Provinsi Jawa Tengah. Semarang: Fakultas Ekonomika Dan Bisnis Universitas Diponegora.

Sopiyanto. (2015). Analisis Peran Sektor Pertanian Dalam Pembangunan Daera Di Kabupaten Batam (Pendekatan Location Quotent Dan Sift Share Analisis. Jakarta.: Fakultas Sains Dan Teknologi Universitas Islam Negeri Syarif Hidayatullah.

Supriadi, Hasbullah. (2015). Analisis Sektor Unggulan Perekonomian Kabupaten Bulukumba.Makassar: Fakultas Ekonomi Dan Bisnis Islam Uin Alaudin Makassar.

Tarigan, Robinson. 2015. Ekonomi Regional Teori Dan Aplikasi. Penerbit PT Bumi Aksara. Jakarta

Trijayanto, Andika Rutara. (2017).Analisis Penentuan Sektor Unggulan Di Dalam Struktur Perekonomian Kabupaten Bojonegoro Provinsi Jawa Timur. Semarang: Fakultas Ekonomi Universitas Diponegoro.

Waluyo, Andik. (2018).Analisis Potensi Ekonomi Dan Sektor Unggulan Ekonomi Di Kabupaten Grobogan Tahun 2010-2015.Surakarta :Fakultas Ekonomi Dan Bisnis Universitas Muhammadiyah Surakarta

Wardani, Aristiyana Nur Tri, Agustono \& Wiwit Rahayu . (2015). Strategi Pembangunan Komuditas Sub Sektor Peternakan Unggulan Di Kabupaten Batam (Analisis Location Quotien Dan Soar).Surakarta: Fakultas Pertanian Universitas Sebelas Maret Surakarta.

Zakaria, T. Zulham \& Gunawan. (2018). Analisis Struktur Ekonomi Kabupaten Aceh Besar. Aceh: Universitas Syah Kuala. 